\title{
Comparison of growth, digestive system maturation and skeletal development in sea bass larvae reared in an intensive or a mesocosm system
}

\author{
Dora Zouiten ${ }^{1}$, Ines Ben Khemis ${ }^{1,4,}$, Ahmed Slaheddin Masmoudi ${ }^{2}$, Christine Huelvan ${ }^{3}$, \\ Chantal Cahu ${ }^{3}$
}

\footnotetext{
1 Laboratoire Aquaculture, Institut National des Sciences et Technologies de la Mer (INSTM), Monastir, Tunisia 2 Institut Supérieur de Biotechnologie de Monastir (ISBM), Rue Taher Hadded, Monastir, Tunisia

3 Département Physiologie Fonctionnelle des Organismes Marins, Institut Français de Recherche pour I'Exploitation de la Mer (Ifremer), Plouzané, France

${ }^{4}$ Present address : Laboratoire Aquaculture, Institut National des Sciences et Technologies de la Mer (INSTM), 28 rue du 2 Mars 1934, 2025 Salammbô, Tunisia.
}

*: Corresponding author : Ines Ben Khemis, Tel.: +216 71730420 ; fax: +216 71732622

email address : ines.benkhmis@instm.rnrt.tn

\begin{abstract}
:
The quality of development in intensive or mesocosm hatchery-reared Dicentrarchus labrax larvae was investigated using physiological indicators assessing ontogeny. Larvae were reared in intensive $(120 \mathrm{~L}$ tanks $)$ and in mesocosm systems $\left(20 \mathrm{~m}^{3}\right.$ enclosures) with the same feeding sequence, excluding the wild zooplankton naturally available in mesocosms. Faster growth was recorded since early development [16 day after hatching (DAH)] in the mesocosm. Maturation of the digestive system also occurred earlier as indicated by the higher amylase secretion ratios, the intestinal maturation index (alkaline phosphatase/leucine-alanine peptidase and aminopeptidase-N/leucine-alanine peptidase ratios) and the more developed intestinal epithelium at $23 \mathrm{DAH}$. Nevertheless, the delay in digestive maturation in the intensive system seemed retrieved within few days. In both the groups, the number of vertebrae ranged between 24 and 26, with the dominant class being 25 vertebrae. However, the distributions differed between treatments for meristic characteristics, ossification stages and incidence of malformation types. Loss of a vertebra was more frequent in the intensive system, while the appearance of an additional vertebra was more frequent in the mesocosm. Ossification at 37 DAH was also more advanced in the mesocosm in addition to a lesser rate and severity of skeletal malformations. It is suggested that the early nutritional contribution of mesocosm wild zooplankton, yet at densities of $0.2-0.7$ prey $\mathrm{mL}^{-1}$, had key effects on larvae development since the early stages.
\end{abstract}

Keywords : fish larvae ; hatchery ; Mesocosm ; Ontogenesis ; Enzyme ; skeletogenesis 


\section{Introduction}

Differences between farmed and wild fish have been emphasized for a variety of finfish species, among which brown trout Salmo trutta (Sundell, Dellefors \& Björnsson, 1998), Atlantic salmon Salmo salar (McCormick and Björnsson, 1994; von Cramon, Ling, Cotter \& Wilkins, 2005), sea bream Sparus aurata, sharpsnout sea bream Diplodus puntazzo and pandora Pagellus erythrinus (Andrades, Becerra \& Fernandez-Llebrez, 1996; Boglione, Gagliardi, Scardi \& Cataudella, S., 2001., Boglione, Costa, Di Dato, Ferzini, Scardi \& Cataudella, 2003), Eurasian perch Perca fluviatilis (Mairesse, Thomas, Gardeur \& BrunBellut, 2005) as well as sea bass Dicentrarchus labrax (Roncarati, Meluzzi, Melotti \& Mordenti, 2001). These differences do not only concern pigmentation features (Pavlidis, Papandroulakis \& Divanach, P, 2006), biochemical composition (Saglik, Alpaslan, Gezgin, Cetintürk, Tekinay \& Güven, 2003; Nasopoulou, Nomikos, Demopoulos \& Zabetakis, 2007), organoleptic characteristics (Grigorakis, Taylor \& Alexis, 2003) or flesh quality (Periago, Ayala, Lopez-Albors, Abdel, Martinez, Garcia-Alcazar, Rosa \& Gil, 2005; Johnston, Li, Vieira, Nickell, Dingwall, Alderson, Campbell \& Bickerdike, 2006). Indeed, wild and reared fish have also been reported to differ in skull and morphological traits (Andrades et al., 1996; Boglione et al., 2003; von Cramon et al., 2005) or in physiological characteristics (McCormick and Björnsson, 1994; Sundell et al., 1998). These functional differences between farmed and wild fish affect their swimming (Smith and Fuiman, 2004) as well as their growth and production performances (Mcdonald, Milligan, Mcfarlane, Croke, Currie, Hooke, Angus, Tufts \& Davidson, 1998; Ogata, Oku \& Murai, 2002). These differences emerge since early stages and appear to be consequences of altered lifestyle conditions during larval development (Roncarati et al., 2001).

Mass production of juveniles for aquaculture can rely on a large variety of hatchery techniques ranging from highly intensive systems incorporating standardized operating procedures and high level of automation to extensive systems, approaching ranching practices. Between these contrasting systems there are multiple intermediate technologies, which include mesocosms, and are generally designated as semi-extensive or semi-intensive depending on adopted classification (van der Meeren and Naas, 1997; Divanach and Kentouri, 2000; Shields, 2001). Distinction between systems takes into accounts factors concerning mainly larval stocking density, tank or enclosure size, water supply, prey source or feed contribution. Practically intensive and semi-extensive technologies could be opposed as systems combining effects high density of larvae and small tanks in absence of natural zooplankton, against low density of larvae in large size enclosures in presence of natural zooplankton respectively. Comparatively to wild specimen, intensive hatchery raised fish are clearly distinguishable (Boglione et al., 2001; von Cramon et al., 2005; Izquierdo, Socorro \& Roo, 2010), while mesocosm reared larvae are recognized to present good similarity (Boglione et al., 2001). Moreover, Loy, Boglione, Gagliardi, Ferrucci \& Cataudella (2000) pointed out significant differences in morphological traits of juvenile sea bass reared during larval stages in mesocosm and intensive technology, despite the later analogous rearing conditions. Roncarati et al. (2001) reported similar final weights but higher total length for fish originating from mesocosm larval rearing. These fish presented a more harmonic shape, similar to that of wild fish, stressing that fingerling origin plays also a fundamental role in a top quality final aquaculture product. Mesocosm reared juveniles are more vulnerable to predation than wild-caught fish (Stunz and Minello, 2001), nevertheless, their qualitative characteristics are among the reasons for which the mesocosm technology is recognized for producing fry dedicated to stock enhancement activities (Shields, 2001). Indeed, steady progress made by stock enhancement programs based on the release of hatchery-raised juveniles has highlighted the importance of physiological, morphological, and ecological characteristics of the juveniles in the success of restocking (Fushimi, 2001; Le Vay, Carvalho, Quinitio, Lebata, Ut \& Fushimi, 2007). 
Sea bass (Dicentrarchus labrax) is an important species for both fisheries and Mediterranean aquaculture. It is well studied with respect to larval growth and development, in particular ontogeny of digestive system (García Hernández, Lozano, Elbal \& Agulleiro, 2001; Zambonino Infante and Cahu, 2001) and skeletal formation (Koumoundouros, Maingot, Divanach \& Kentouri,., 2002; Sfakianakis, Georgakopoulou, Papadakis, Divanach, Kentouri \& Koumoundouros, 2006; Villeneuve, Gisbert, Moriceau, Cahu \& Zambonino Infante, 2006). However, to the best of our knowledge, most of the studies have been carried out on laboratory or intensive hatchery-reared larvae and studies concerning mesocosm-reared larvae are particularly scarce (Georgalas, Malavasi, Franzoi \& Torricelli, 2007) even though their conditions are closer to field environment. Knowledge concerning early development of fish larvae is not only interesting for larviculture management but it is also valuable in fisheries studies. Indeed, understanding the phenotypic and functional variation between ontogenetic stages of larvae is critical because it is related to profound demographic consequences in populations (Koumoundouros, Ashton, Xenikoudakis, Giopanou, Georgakopoulou \& Stickland, 2009).

The main objective of this work was to compare quality of development in mesocosm or intensive hatchery-reared sea bass (Dicentrarchus labrax L. 1758) larvae, As the digestive enzyme pattern and skeletal formation has been described to be closely related to development in fish larvae (Zambonino Infante and Cahu, 2001; Villeneuve et al., 2006; Kvåle, Mangor-Jensen, Moren, Espe \& Hamre, 2007), these parameters were chosen as early physiological indicators for assessing potential differences between larvae development in intensive and mesocosm system.

\section{Materials and methods}

Newly hatched larvae issued from a same batch of eggs were reared with each technology i.e. in an experimental system combining no natural zooplankton, small tanks and high density of larvae in comparison to an experimental system combining effect of natural zooplankton, large enclosure and low density of larvae respectively.

\subsection{Larvae and rearing unites}

The study was realized at the marine aquaculture center of INSTM "Institut National des Sciences et Technologies de la Mer" at Monastir (Tunisia). Sea bass eggs were provided by the hatchery of the marine farm Aquaculture Tunisienne (Chott Meriem, Tunisia) and were incubated in cylindro-conic polyester-glass fibre tanks of $120 \mathrm{~L}$, provided with aeration and a flow through of filtered and UV sterilized sea water. The newly hatched larvae were seeded at the stocking densities of 90 larvae $\mathrm{L}^{-1}$ and 3 larvae $\mathrm{L}^{-1}$ for the intensive and the mesocosm treatment respectively. Three cylindro-conic polyester-glass fibre tanks of $120 \mathrm{~L}$ capacity were used for intensive rearing. These tanks were connected to a closed recirculation system equipped with a biological filter, a sand filter and UV sterilization. Three cylindrical concrete tanks of $20 \mathrm{~m}^{3}$ capacity and coated with PVC liner were used as mesocosm enclosures. They were supplied with sea water pumped in the Laguna of Khniss (Monastir, Tunisia) and filtered on a $360 \mu \mathrm{m}$ mesh. The enclosures were protected by a polyester-glass fibre greenhouse and shaded by individual black agricultural curtains fixed horizontally at $2 \mathrm{~m}$ over the water surface. They were operated and monitored as described in Ben Khemis, Zouiten, Besbes \& Kamoun (2006) and Zouiten, Ben Khemis, Besbes \& Cahu (2008). Mean water temperature was $22.9 \pm 2.3^{\circ} \mathrm{C}$ in mesocosm enclosures and $22.2 \pm 1.3^{\circ} \mathrm{C}$ in intensive tanks. Mean oxygen saturation level was $84.7 \pm 13.8 \%$ in mesocosm and $91.4 \pm 10.6 \%$ in intensive tanks. Water salinity and $\mathrm{pH}$ were $37.5 \pm 0.5 \%$ and $8.2 \pm 0.1$ respectively. 
The larvae in both treatments were fed newly hatched Artemia type $\mathrm{AF}^{\circledR}$ (INVE Aquaculture, INVE Dendermonde, Belgium) from 9 until 20 day after hatching (DAH). Then, also in both treatment, they received from 19 to $28 \mathrm{DAH}$ one day old Artemia type $\mathrm{EG}^{\circledR}$ (INVE Aquaculture, INVE Dendermonde, Belgium) enriched with DC-Super Selco ${ }^{\circledR}$ (INVE Aquaculture, INVE Dendermonde, Belgium) according to the instructions provided by the manufacturer. Under standard mesocosm rearing conditions, hatchery produced live preys are generally distributed to avoid overgrazing of zooplanktonic blooms by the larvae. These distributed preys do not necessarily need to be enriched since they may get naturally enriched by grazing phytoplankton within rearing enclosures. Nevertheless, in present study, enriched Artemia were also fed to mesocosm reared larvae with the intent to use qualitatively similar feeding sequences in the two treatments, excluding the wild zooplankton naturally available in mesocosms. Density of Artemia ranged between 0.1 and 0.3 individual $\mathrm{ml}^{-1}$ in mesocosm enclosures and was maintained at 10 individual $\mathrm{ml}^{-1}$ in intensive tanks. These densities were considered sufficient to guarantee satiation of the larvae, as indicated by remaining preys in rearing water of each system and observation larvae gut fullness. In addition to Artemia, the larvae of the mesocosms consumed the wild plankton naturally developing in the enclosures. Density of potential zooplankton preys, which was estimated as described in Zouiten et al (2008), varied between 0.2 and 0.7 prey $\mathrm{ml}^{-1}$ during the two first weeks of larval development. Wild zooplankton community was dominated first by rotifers (mainly Brachionous plicatilis) and next by a multispecific bloom of nauplii and copepodites in addition to few other prey types (ciliates, annelid larvae and few trocophores). For the period of co-feeding with formulated diet (22 to $28 \mathrm{DAH})$ and after weaning, the commercial diets Replace $^{\circledR}$ II A $(100-150 \mu \mathrm{m})$ and Replace ${ }^{\circledR}$ II B $(100-200 \mu \mathrm{m})$ from RICH S.A. (RICH S.A, Athens, Greece) were distributed in excess. These diets were dispensed manually every 20 to $30 \mathrm{~min}$ from 08:00 to $19: 00 \mathrm{~h}$.

\subsection{Sampling and Analysis}

Larvae were sampled in each enclosure or tank on day $0,8,16,23,30$ and $37 \mathrm{DAH}$, early in the morning always before any food distribution.

For growth study, 20 larvae were anesthetized with ice-cold seawater, fixed with glutaraldehyde (2.5\% in phosphate buffered solution $\mathrm{pH} 7.4)$ and kept refrigerated until length and weight measurement. Photographs of the fish were taken using a digital camera (Nikon Coolpix 4500) mounted on a trin-ocular stereomicroscope (Hund Wetzlar) and length measurements were carried out using image analysis software WCIF ImageJ 1.37c. An object micrometer was photographed with each set of photos to avoid errors due to the autofocus of the camera. After photography, fixed larvae were dried out on blotting paper and next weighed to the nearest $0.1 \mathrm{mg}$ with an analytical balance (Denver Instrument APX 200). Larvae were weighed individually, except for specimens of less than $5 \mathrm{mg}$ for which pooled weights were taken.

At the end of the trial, it was not possible to determine real survivals due to zoo-technical difficulty of handling larvae from $20 \mathrm{~m}^{3}$ enclosures as well as relative incidence of repetitive sampling in small intensive enclosures. However, additional 30 larvae from each tank or enclosure, were sampled and anesthetized with ice-cold seawater before fixation with formaldehyde $(10 \%$ in phosphate buffered solution $\mathrm{pH} 7.4)$ in order to examine larvae skeletal development and vertebra number as well as identification of malformations. The fixed samples were bleached with $\mathrm{KOH}$ and peroxide treatment and then double stained with alcian blue for cartilaginous structures and alizarin red $\mathrm{S}$ for ossified structures according to the procedure described by Taylor and Van Dyke (1985). Stained samples were stored in glycerol containing a crystal of thymol until later numerization. In brief, glycerol conserved samples were poured into a Petri dish in which larvae were let to sediment on their side. A global digital image with a resolution of 3200 dpi was then obtained using a scanner EPSON 
4990 PHOTO and Adobe Photoshop CS software. Afterwards, a sub-image was extracted for each larva. Developmental stages (table 1) were determined using the morphological criterions adapted to sea bass larvae (Vagner, Robin, Zambonino Infante \& Person-Le Ruyet, 2007). Study of skeletal malformations focused on severe body skeletal deformities (i.e. later externally visible) in addition to the incidence of vertebral compression or fusion with no apparent body distortion. The severe body skeletal malformations were limited to deformities of vertebral column (lordosis, scoliosis, or kyphosis) and mouth (lower jaw prognathism or retracted maxillary). Operculum deformities were not counted as only one side of stained fish was photographed. Data were presented as relative frequencies distributions.

For enzymatic assay, samples of 150, 125, 100, 50, 40 and 30 larvae were collected from each rearing tank or rearing enclosure on the respective sampling days. They were immediately stored at $-80^{\circ} \mathrm{C}$ pending assay. Before homogenizing in ice cold distilled water, the larvae were gently vortexed in $500 \mu \mathrm{l}$ ice cold distilled water during $30 \mathrm{sec}$ to obtain released pancreatic enzymes in the supernatant (S1) for samples of 0,8 and $16 \mathrm{DAH}$. This supernatant contained the secreted trypsin and amylase (Ma, Cahu, Zambonino, Yu, Duan, Le Gall \& Mai, 2005). The larvae were then homogenized in 1 to $2 \mathrm{ml}$ ice cold distilled water with a homogenizer (Polytron, PT-MR 2100) during $30 \mathrm{sec}$ and then centrifuged at 3300 $\times \mathrm{g}$ for $3 \mathrm{~min}$. This supernatant (S2), was used to analyze unreleased pancreatic enzymes (trypsin and amylase) and intestinal enzymes (alkaline phosphatase [AP], aminopeptidase N [AN] and leucine-alanine peptidase [Leu-ala]). Larvae from 23, 30 and $37 \mathrm{DAH}$ were dissected as described by Cahu and Zambonino Infante (1994), in order to separate pancreatic segment (PS) and intestinal segment (IS). Dissection was conducted on a glass plate maintained at $0{ }^{\circ} \mathrm{C}$ (on crushed ice) under a stereomicroscope. Pancreatic segments were homogenized in $2 \mathrm{ml}$ ice cold distilled water and processed as described above for enzymes assays. Intestinal segments were homogenized in 30 volumes (v/w) of TrisMannitol buffer (2 Mm-50 mM, pH 7). One $\mathrm{ml}$ of homogenate was removed in order to assay secreted pancreatic enzymes, the cytosolic leucine-alanine peptidase and alkaline phosphatase. The remaining homogenate was used to purify brush border membranes (BBM) according to the method adapted to fish larvae intestinal segments (Cahu and Zambonino Infante, 1994). The purified BBM were used to assay both [AP] and [AN]. The pancreatic enzymes, amylase and trypsin, activities were assayed according to Métais \& Bieth (1968) and Holm, Hanssen, Krogdahl, \& Florholmen (1988), respectively. The intestinal BBM enzymes [AP] and [AN] were assayed according to Bessey, Lowry \& Brock (1946) and Maroux, Louvard \& Baratti (1973). Assay of the intestinal cytosolic enzyme [leu-ala] was performed using the method of Nicholson \& Kim (1975). Amylase activity was expressed as the equivalent enzyme activity required for hydrolyzing $1 \mathrm{mg}$ of starch in $30 \mathrm{~min}$ at $37^{\circ} \mathrm{C}$ (Zambonino Infante \& Cahu, 1994). Protein was determined by the Bradford procedure (Bradford, 1976). Enzyme specific activities were expressed as $\mu$ moles of substrate hydrolysed $\mathrm{min} / \mathrm{mg}$ protein at $37^{\circ} \mathrm{C}$ for $\mathrm{AP}$, leu-ala and $\mathrm{AN}$, and at $25^{\circ} \mathrm{C}$ for trypsin (Zambonino Infante \& Cahu, 1994). Trypsin and amylase activities were expressed as segmental activities, i.e., activity per larva in each sample fraction ( $\mathrm{mU}$ or U/larvae). Then the relative contribution of the activity of released fraction to total activity was calculated as S1/(S1 + S2) or IS/(IS + PS) for un-dissected and dissected sampled larvae respectively. This ratio reflects the secretion level of pancreatic enzymes (Zambonino Infante, Cahu, Péres, Quazuguel \& Le Gall, 1996).

For histological analysis, Bouin's fixed larvae were embedded in paraffin, and serial sagittal sections of $6 \mu \mathrm{m}$ thick were stained with the Masson Goldner trichromic technique (Masson, 1929). Preparations were observed under a microscope (Axiolab Zeiss) and photographed with a digital camera (Axiocam HR Zeiss). Measurements were acquired using image analysis software WCIF Image J 1.37c. 


\subsection{Statistical analyses}

The results are given as means \pm SD of replicate groups except for vertebrae number and skeletal developmental stages because samples had been pooled before chemical treatment. To obtain normality of the data, they were log transformed for body weights and $\arcsin \left(x^{1 / 2}\right)$ transformed for pancreatic enzymes (trypsin and amylase) secretion rates and ratios of segmental intestinal enzyme activities (maturation index). The normality and homogeneity of the transformed data were checked with Kolmogorov-Smirnov's and Box's M tests, respectively. These results were first analyzed with two-way analysis of variance (ANOVA), the analyzed factors being larvae age and experimental treatment jointly with the interaction effect of factors. When no interaction between factors was detected (the case for growth and intestinal maturation index) additional separate one-way ANOVA was performed for each significant factor effect, i.e. between technologies for each age and between ages for each technology. When a significant interaction between factors was detected (the case for trypsin and amylase secretion rates) homogenous groups were determined with interaction factor effect. Results on histological measurements were compared by one-way ANOVA after verification of normality and homogeneity of the data with KolmogorovSmirnov's and Levene's tests, respectively. The Newman-Keuls test was applied for post-hoc comparisons when differences were found at the $(\alpha=5 \%)$ for all the ANOVA. The MannWhitney test for ordinal data was used for testing differences between distributions of vertebrae number, ossification stages and incidence of the different types of deformities. All statistics were performed using the software Statistica 5.5 (StatSoft, Inc.) and Zar (1999) was used as reference.

\section{Results}

\subsection{Larvae growth}

The larvae weighed $0.33 \pm 0.03 \mathrm{mg}$ (wet weight of $2.5 \%$ glutaraldhyde fixed larvae) and measured $3.3 \pm 0.5 \mathrm{~mm}$ total lengths at hatching. The two-way ANOVA indicated highly significant effects $(P<0.01)$ of both larval age and treatment factors but interaction was not significant $(P=0.399)$. Weights (Fig. 1$)$ differed significantly between treatments since day 16 $\mathrm{DAH}$ and reached the final body weights of $21.45 \pm 2.78 \mathrm{mg}$ and $57.27 \pm 15.56 \mathrm{mg}$ for 37 days old larvae from intensive and mesocosm treatments respectively.

\subsection{Ontogeny of digestive system}

In both treatments, secretion ratios of pancreatic enzymes presented patterns showing progressive increases with larval age. The two-way ANOVA revealed that age and treatment interaction was significant $(P=0.034)$ and highly significant $(P=0.009)$ for trypsin and amylase secretion ratios respectively. Trypsin secretion ratio (Fig. 2a) of larvae reared in intensive was only the half of that observed in larvae reared in mesocosm at $8 \mathrm{DAH}$. After this day, no differences were observed in trypsin secretion ratios between the two treatments. From 23 $\mathrm{DAH}$, secretion of this enzyme reached a plateau, about $50 \%$, in both treatments. Early amylase secretion ratios (Fig. 2b) were around $40-50 \%$ and did not differ between treatments until $23 \mathrm{DAH}$. At this stage, the ratio reached a plateau around $90 \%$ in mesocosm reared larvae. Comparatively, pancreas maturation of intensively reared larvae seemed less advanced as amylase secretion ratios maintained at a lower level until $30 \mathrm{DAH}$ and reached the final level on $37 \mathrm{DAH}$.

Specific activities of the AP assayed in larvae homogenates or intestinal segment homogenates (day 23 and onwards), remained below $200 \mathrm{mU} / \mathrm{mg}$ protein and varied similarly in both experimental treatments. In the purified BBM (day 23 and onwards), AP 
specific activities showed more than a 7-fold increase, indicating a good purification. Intestinal maturation index (table 2), corresponding to relative expressions of segmental intestinal BBM enzymes (AP or AN) to the cytosolic enzyme (Leu-ala), differences were related to both age and treatment factors while the interaction was not significant. The index was only a third in 23 day old larvae reared in intensive compared to those in larvae reared in mesocosm. From $30 \mathrm{DAH}$, this ratio did not differ with treatment. Indeed, from 23 to $30 \mathrm{DAH}$, maturation index in larvae reared in intensive increased up to a similar value comparatively to those in larvae reared in mesocosm. The intestinal epithelium observed in histological preparations of 23 day old larvae showed well differentiated enterocytes with similar (oneway ANOVA; $\mathrm{P}=0.194)$ heights in both treatments $(22 \pm 4$ and $25 \pm 4 \mu \mathrm{m}$ for intensive and mesocosm respectively). However, mucosal folds in middle intestine appeared poorly developed $(37 \pm 7 \mu \mathrm{m})$ in larvae reared in intensive while they were well developed and significantly (one-way ANOVA; $\mathrm{P}<0.05)$ higher $(82 \pm 9 \mu \mathrm{m})$ in same age larvae $(23 \mathrm{DAH})$ reared in mesocosm (Fig. 3).

\subsection{Skeletal formation}

Concerning meristic character, the dominant class corresponded to 25 vertebrae in both experimental groups (Fig. 4a). Nevertheless, dispersions of vertebrae number differed significantly between treatments. Both groups contained specimens with 24 or 26 vertebrae instead of 25 , however, the loss of a vertebra was more frequently observed in the intensively reared larvae (26.4\% vs. 5.2\%) while the appearance of an additional vertebra was more frequently observed in the mesocosm reared larvae (13.6 \% vs. 3.8\%). Skeletal development (Fig. 4b) of 37 days old fish from the intensive rearing was quite evenly distributed between stages $A$ and $B$ while that of fish from mesocosm rearing was distributed between stages $\mathrm{C}$ to $\mathrm{E}$; indicating obviously a more advanced skeletal development in this treatment (Fig 5a) compared to intensive treatment (Fig 5b). The incidence of the different types of deformities differed between treatments (Fig 6). In intensive, $41.5 \%$ of the fish exhibited severe body skeletal deformities, in addition to $1.9 \%$ with caudal fusioned vertebrae. In mesocosm, less than $7.7 \%$ of the fish exhibited severe malformation but $19.4 \%$ presented fusion of vertebrae in the caudal region with no apparent body distortion.

\section{Discussion}

In our study, the larvae were originated from the same batch of eggs and were reared under similar thermal conditions allowing the comparison of the influence of each of the studied hatchery technology on larvae growth and ontogeny. Larval growth obtained in both intensive or mesocosm technologies were close to those reported for the species by other authors (Kotzamanis, Gisbert, Gatesoupe, Zambonino Infante, \& Cahu, 2007; Georgalas et al. 2007). They differed in the advantage of mesocosm and it can be inferred that the observed disparity of growth ought to be effectively related to the rearing technology which affected larvae since early development. Indeed, the difference of growth was detectable as early as $16 \mathrm{DAH}$ and maintained throughout the end of the experiment. Recently, similar results were reported for growth of red porgy Pagrus pagrus, in a study concerning effects of rearing techniques on larvae development (Roo, Socorro \& Izquierdo, 2010). However, in present study, it is difficult to determine precisely which of the variables (larval density, prey abundance, tank size, water turbidity, etc.), or their combination, differing between distinct experimental conditions were causing the difference of growth observed between the treatments. Prey abundance (Duffy, Epifanio \& Cope, 1996; Clemmesen, Bühler, Carvalho, Case, Evans, Hauser, Hutchinson, Kjesbu, Mempel, Moksness, Otterå, Paulsen, Thorsen \&, Svåsand, 2003; Georgalas et al., 2007), enclosures size (Clemmesen et al., 2003), water turbidity and turbulence (Utne-Palm, 2004), are known to affect fish larvae feeding and growth. 
In both experimental groups, trypsin and amylase secretion ratios presented patterns showing progressive increases with larval age and corresponding to the normal maturation of exocrine pancreas described in sea bass larvae (Zambonino Infante and Cahu, 2001). Nonetheless, a higher trypsin secretion ratio was observed in 8 DAH mesocosm reared larvae compared to intensive reared larvae. Considering feed distribution sequence, this difference could be related to larvae feeding status at that time. Indeed, 8 DAH was before the onset of exogenous feeding in intensive treatment, as Artemia distribution was not yet initiated, while in mesocosm enclosures, larvae were already in presence of wild zooplankton that they consumed readily. In fish larvae, it was demonstrated that trypsin activity responds to both dietary rations and contents (Zambonino Infante et al., 1996; Péres, Zambonino Infante \& Cahu, 1998; Pedersen, Ueberschär \& Kurokawa, 2003). Increased trypsin-like total proteolytic activity was also reported by Kolkovski (2001) in young (3-18 DAH) gilthead seabream larvae when visual (preys) or chemical (water from Artemia rearing tank or even supernatant of centrifuged liquid krill hydrolysate, containing FAA and other compounds found to be feed attractants) stimuli were introduced to the larval rearing water without any feed. In mesocosm reared larvae, a similar potential stimulation of pancreatic activity could also be supposed. Especially since no anymore difference of trypsin secretion between treatments was observed, after beginning of Artemia or diet distribution. The lower amylase secretion rate observed in 23 and 30 days old larvae from intensive rearing indicated that pancreas maturation was less advanced in the larvae of this treatment, comparatively to mesocosm reared larvae.

Development of intestinal structures has been extensively described in the larvae of several fish species: during ontogenesis, the intestine gets elongated, the intestinal mucosa and fold height increase leading to the increase of intestinal digestion and absorption area (Gatesoupe, Zambonino Infante, Cahu \& Bergot, 1999; García Hernández et al., 2001; OrtizDelgado, Darias, Cañavate, Yúfera \& Sarasquete, 2003). This development is accompanied by the enhancement of enterocytes BBM enzymatic activities, which a sharp increase notably characterizes intestinal maturation (Kvåle et al., 2007). In some species, including sea bass larvae (Zambonino Infante and Cahu, 2001), this sharp increase in BBM enzymes is associated with a coexisting decrease in cytosolic enzymes activities of enterocytes. Hence, intestinal maturation is often assessed by AP/Leu-ala and AN/Leu-ala ratios which are considered good indicators of intestinal maturation (Zambonino Infante and Cahu, 1994). Intestinal maturation index obtained in this study were comparable to those reported in sea bass larvae by these previous authors or in other species like large yellow croaker (Pseudosciaena crocea) or thick lipped grey mullet (Chelon labrosus) (Ma et al., 2005; Zouiten et al., 2008). The results revealed that the larvae from the intensive rearing acquired the adult mode of intestinal digestion between 23 and $30 \mathrm{DAH}$ which is in agreement with the normal intestinal maturation process of sea bass larvae reported by (Zambonino Infante and Cahu, 2001). Together with the enzymatic data, the well developed mucosa shows that mesocosm reared larvae have already achieved their intestinal maturation at day 23 ph while intensive reared larvae still maintained a larval mode of digestion at this stage.

Histological observations of intestine as well as other digestive organs, constitute a good indicator of the nutritional condition of larvae as it was shown in carp Cyprinus carpio fed experimental diets (Przybyl, Ostaszewska, Mazurkiewicz \& Wegner, 2006; Zhou, Zhao \& Lin, 2007) or sea bass submitted to partial starvation (Papadakis, Zaiss, Kyriakou, Georgiou, Divanach \& Mylonas, 2009). The well developed fold observed as early as 23 DAH in mesocosm reared larvae suggest that the phytoplankton and zooplankton naturally produced in the enclosures constitute a consistent trophic supply. As usually observed in mesocosms plankton assemblages under studied geo-climatic context, zooplankton was initially dominated by rotifers and then by copepods (Ben Khemis et al., 2006), known as preferential preys for fish larvae. In addition, the phytoplankton in mesocosms may have triggered the maturation of both pancreatic and intestinal function, as it was shown in Cahu, Zambonino 
Infante, Péres, Quazuguel \& Le Gall (1998), leading to a better efficiency for assimilating the consumed feed in this treatment. These conditions, met in mesocosm, evidently should have allowed the larvae to attain a better nutritional status and have contributed to enhance their growth performance comparatively to those from intensive treatment. The difference of growth between the larvae was obviously related to the difference in maturation of digestive system. Vice a versa, the difference in digestive maturation was evidently related to the difference of growth. Indeed, in fish larvae, stages of development are rather linked to larval size than larval age (Fuiman, 1983; Osse, Van den Boogaart, Van Snick \& Van der Sluys, 1997; Vagner et al., 2007). It would have been interesting to compare between intensive and mesocosm larvae with similar size and check if the delay in digestive maturation coincided exactly with the delay of growth observed in intensive treatment. Unhopefully, the sampling interval (about once a week) was too large and did not allow such comparison. Nevertheless, since larvae from both treatments were reared under similar thermal conditions, did not differ genetically, did not experience any trophic restrictions, and received the same diets, results of present study globally pointed out that growth was faster and maturation of digestive system occurred beforehand in mesocosm reared larvae. They also indicated that the delay in digestive maturation of intensively reared larvae was retrieved within few days.

Skeleton is a complex metabolically active tissue that undergoes continuous remodelling throughout fish life (Lall and Lewis Mc-Crea, 2007). Osteological development including formation of meristic characters and emergence of major deformities, are established during early larval ontogeny (Andrades et al., 1996; Koumoundouros, Divanach \& Kentouri, 1999; Villeneuve et al., 2006). Both meristic characters (Fowler, 1970) and skeletal deformities (Koumoundouros, Divanach \& Kentouri, 2001; Koumoundouros et al.2002; Boglione et al., 2003; Boglione, Marino, Giganti, Longobardi, De Marzi \& Cataudella, 2009) are known to be affected by genetic and environmental factors. The results concerning meristic characteristics indicated that in both groups the number of vertebrae ranged between 24 and 26 with the dominant class corresponding to 25 vertebrae. This is in agreement with commonly reported meristic counts in sea bass (Bouain, 1977). However, the loss of a vertebra was more frequently observed in the intensively reared larvae while the appearance of an additional vertebra was more frequently observed in the mesocosm reared larvae. This is consistent with the study of Koumoundouros et al. (2001) concerning the meristic characters of young Dentex dentex reared with different techniques and compared to wild juveniles. The authors reported that meristic characters of the normal reared fish were not differentiated from those of the wild, but they presented higher variability. Contrastingly to present observation, it was shown that intensification increased the number of vertebrae in red porgy (Izquierdo et al., 2010). All together, these results contribute to support the specificity of fish species response to some potentially affecting factors during larval development.

Similarly to distributions of meristic character at the end of the experiment, results concerning both osteological development and incidence of malformation types showed different distributions between treatments. Osteological development appeared more advanced in mesocosm than in intensive reared larvae. This is in agreement with results of Roo et al. (2010) which reported that red porgy larvae showed patterns differing in timing of apparition and ossification of skeletal elements. Rates and severity of skeletal malformations were lesser in mesocosm; and in addition fusion of vertebrae in the caudal region with no apparent body distortion represented the main type of malformation in this treatment. In sea bream, this type of malformation has been recently reported to might be a result of nutritionally induced accelerated skeletogenesis (Fernández, Hontoria, Ortiz-Delgado, Kotzamanis, Estévez, Zambonino-Infante \& Gisbert, 2008).

Overall, the difference in osteological development between the two groups is in agreement with several studies concerning influence of rearing conditions or techniques on juvenile quality (Koumoundouros et al., 2001, 2002; Sfakianakis et al., 2006; Boglione et al., 2009; Izquierdo et al., 2010; Roo et al., 2010). This skeletogenesis difference might be related to 
the diverse conditions provided by each rearing technique and which might concern tank size, larval density, light, water turbidity, current velocity, preys types and concentration, etc. The experimental design of the present study does not allow isolating clearly the specific causative factors and their level of contribution to explain this difference. However, temperature, which is known to be a major factor affecting larvae osteological development (Lewis, Lall \& Witten., 2004; Sfakianakis et al., 2006), can be excluded as it did not differ between treatments. Similarly, genetic cannot be evoked as the larvae of present study were issued from a same egg batch. Nevertheless, in view of vertebrae counts distributions, it is suggested that feeding conditions during the first days of larvae development were among the major affecting factors. Indeed, several dietary factors are recognized to play a key role in bone metabolism and to affect skeletal development (Cahu, Zambonino Infante \& Takeuchi, 2003; Lall and Lewis Mc-Crea., 2007). Villeneuve et al. (2006) showed that some nutrients, like phospholipids and vitamin A, affect European sea bass morphogenesis and act particularly on the number of vertebrae, during the specific window of time corresponding to 8-13 DAH. Early larval nutrition (4-18 DAH) was also shown to exert a strong effect on skeletogenesis and the further larval performance in sea bream (Fernández et al., 2008). Comparatively to intensive hatchery-reared larvae, larvae in mesocosm were able to feed on wild plankton beside enriched added preys, hence it can be inferred that nutritional contribution of mesocosm wild zooplankton had key effects on larval development yet at densities of 0.2 to 0.7 prey $\mathrm{ml}^{-1}$. These densities were low relatively to distributed reared preys but were not negligible if compared to prey densities reported for favourable growth of fish larvae of several species in the wild or in mesocosm (Duffy et al., 1996; Clemmesen et al., 2003; Ben Khemis et al., 2006).

The skeletal system consists of bones and cartilage and serves multiple physiological functions, of which the most important is by far to support the structural integrity of the body for normal posture, development and locomotion (Lall and Lewis Mc-Crea., 2007). Skeletal ossification during ontogenesis is a crucial event for later proper achievement of these functions. In this study, skeletal development of 37 days mesocosm reared larvae was clearly more advanced. As fish larvae ossification is size dependent (Vagner et al., 2007; Kjørsvik, Olsen, Wold, Hoehne-Reitan, Cahu, Rainuzzo, Olsen, Øie \& Olsen, 2009), it is obviously related to their bigger size, evidently a consequence of a comparatively better nutritional status. Conversely, the more advanced skeletal development state might have contributed to ameliorate larvae nutritional status by improving their predation efficiency. Indeed, development of locomotion is crucial both for predator avoidance and for food capture efficiency (van Snik, van den Boogaart \& Osse, 1997). Intensively reared red drum (Sciaenops ocellatus) larvae have been reported to present altered mean routine swimming speed and time to response for a visual stimulus comparatively to wild larvae (Smith and Fuiman, 2004). Similarly to meristic characters, nutritional factors from wild zooplankton might also have contributed to amelioration of ossification, especially thanks to the phospholipids and the highly unsaturated fatty acids content of wild zooplankton (Ruiz, Amat \& Navarro, 2008; van der Meeren, Olsen, Hamre \& Fyhn, 2008). Indeed, these dietary compounds have been shown to induce beneficial effect on the ossification process in sea bass larvae (Vagner et al., 2007) and in Atlantic cod (Gadus morhua) larvae as well (Kjørsvik et al., 2009).

\section{Conclusion}

Digestive system maturation assessed both by enzymatic activities and histological structure of intestine, and skeletal development, assessed by vertebra number, ossification level, and typology of deformities, constitute pertinent indicators to qualify fish larval development. In this study, these indicators showed that development occurs at earlier stage in mesocosm reared larvae. The delay in digestive function maturation is retrieved within few days for 
intensive reared larvae. Mesocosm wild zooplankton, even at low density, would have major nutritional effects on larval ontogenesis, markedly on skeletogenesis and development of meristic characters.

\section{Acknowledgements}

This work was supported by the research funds of the INSTM and beneficed of the cooperation with Ifremer, supported by the Embassy of France in Tunisia. Particular thanks are addressed to the hatchery staff of the INSTM for the help, to Pr. Badreddine Sriha (Laboratoire d'anatomie et de cytologie pathologiques at CHU Fahret Hached - Sousse) for aid concerning histology, as well as Dr. José Zambonino-Infante and Mrs Marie Madeleine le Gall (UMR 1067 Nutrition des Poissons at Ifremer) for their advice and support concerning biochemical analysis.

\section{References}

Andrades, J.A., Becerra, J., Fernandez-Llebrez, P. (1996) Skeletal deformities in larval, juvenile and adult stages of cultured gilthead seabream (Sparus aurata L.). Aquaculture 141, 1-11.

Ben Khemis, I., Zouiten D., Besbes, R., Kamoun, F. (2006) Larval rearing and weaning of thick lipped grey mullet (Chelon labrosus) in mesocosm with semi-extensive technology. Aquaculture 259, 190-201.

Bessey, O.A., Lowry, O.H., Brock, M.J. (1946) Rapid coloric method for determination of alkaline phosphatase in five cubic millimeters of serum. J. Biol. Chem. 164, 321- 329.

Boglione, C., Costa, C., Di Dato, P., Ferzini, G., Scardi, M., Cataudella, S. (2003) Skeletal quality assessment of reared and wild sharpsnout sea bream and pandora juveniles. Aquaculture 227, 373-394.

Boglione, C., Gagliardi, F., Scardi, M., Cataudella, S. (2001) Skeletal descriptors and quality assessment in larvae and post-larvae of wild-caught and hatchery-reared gilthead sea bream (Sparus aurata L. 1758). Aquaculture 192, 1-22.

Boglione, C., Marino, G., Giganti, M., Longobardi, A., De Marzi, P., Cataudella, S. (2009) Skeletal anomalies in dusky grouper Epinephelus marginatus (Lowe 1834) juveniles reared with different methodologies and larval densities. Aquaculture 291, 48-60.

Bouain A. (1977) Etude des caractères morphologiques et anatomiques de Dicentrarchus labrax (Linne, 1758) et de Dicentrarchus punctatus (Bloch, 1792) des côtes tunisiennes. Bulletin de la Société des Sciences nataturelles de Tunisie 12, 57-68.

Bradford, M.M. (1976) A rapid and sensitive method for the quantitation of microgram quantities of protein utilizing the principle of protein-dye binding. Analytical biochemistry $72,248-254$.

Cahu C.L and Zambonino Infante J.L (1994) Early weaning of sea bass (Dicentrarchus labrax) larvae with a compound diet: Effect on digestive enzymes. Comparative Biochemistry and Physiology Part A: Physiology 109(2), 213-222

Cahu, C., Zambonino Infante, J.L., Péres, A., Quazuguel,, P., Le Gall, M.M. (1998) Algal addition in sea bass (Dicentrarchus labrax) larvae rearing: effect on digestive enzymes. Aquaculture 161, 479-489.

Cahu, C., Zambonino Infante, J., Takeuchi, T. (2003) Nutritional components affecting skeletal development in fish larvae. Aquaculture 227, 245-258.

Clemmesen, C., Bühler V., Carvalho, G., Case, R., Evans, G., Hauser, L., Hutchinson, W.F., Kjesbu, O.S., Mempel, H., Moksness, E., Otterå, H., Paulsen, H., Thorsen, A., Svåsand, T. (2003) Variability in condition and growth of Atlantic cod larvae and juveniles reared in mesocosmos: environmental and maternal effects. Journal of fish Biology 62, 706-723. 
Divanach, P., Kentouri, M. (2000) Hatchery techniques for specific diversification in Mediterranean finfish larviculture. In Recent Advances in Mediterranean Aquaculture Finfish Species Diversification. Cahiers Option Méditerranéennes 47, 75-87.

Duffy, J.T., Epifanio, C.E., Cope, J.S. (1996) Effects of prey density on the growth and mortality of weakfish Cynoscion regalis (Bloch and Schneider) larvae: experiments in field enclosures. Journal of Experimental Marine Biology and Ecology 202, 191-203.

Fernández, I., Hontoria, F., Ortiz-Delgado, J.B., Kotzamanis, Y., Estévez, A., ZamboninoInfante, J.L., Gisbert, E. (2008) Larval performance and skeletal deformities in farmed gilthead sea bream (Sparus aurata) fed with graded levels of Vitamin A enriched rotifers (Brachionus plicatilis). Aquaculture 283, 102-115.

Fowler, J.A.,) (1970) Control of vertebral number in teleosts - an embryological problem. The Quarterly Review of Biology 45, 148-167.

Fuiman, L.A. (1983) Growth gradients in fish larvae. Journal of Fish Biology, 23, 117-123.

Fushimi, H. (2001) Production of juvenile marine finfish for stock enhancement in Japan. Aquaculture 200, 33-53.

García Hernández, M.P., Lozano, M.T., Elbal, M.T., Agulleiro, B. (2001) Development of the digestive tract of sea bass (Dicentrarchus labrax L). Light and electron microscopic studies. Anatomy and Embryology, 204, 39-57.

Gatesoupe, F.J., Zambonino Infante, J.L., Cahu, C., Bergot, P. (1999) Ontogénèse, développement et physiologie digestive chez les larves de poisson. Chapitre 12, In : Nutrition et alimentation des poissons et des crustacés. J. Guillaume, S. Kaushik, P. Bergot \& R. Métailler (éd.), INRA édition, Paris : 249-264.

Georgalas, V., Malavasi, S., Franzoi, P., Torricelli, P. (2007) Swimming activity and feeding behaviour of larval European sea bass (Dicentrarchus labrax L): Effects of ontogeny and increasing food density. Aquaculture 264, 418-427.

Grigorakis, K., Taylor, K.D.A., Alexis, M.N. (2003) Organoleptic and volatile aroma compounds comparison of wild and cultured gilthead sea bream (Sparus aurata): sensory differences and possible chemical basis. Aquaculture 225, 109-119.

Holm, H., Hanssen, L.E., Krogdahl, A., Florholmen, J. (1988) High and low inhibitor soybean meals affect human duodenal proteinase activity differently: in vivo comparison with bovine serum albumin. Journal of Nutrition 118, 515- 520.

Izquierdo, M.S., Socorro, J., Roo, J. (2010) Studies on the appearance of skeletal anomalies in red porgy: effect of culture intensiveness, feeding habits and nutritional quality of live preys. Journal of Applied Ichthyology 26, 320-326.

Johnston, I.A., Li, X., Vieira, L.A., Nickell, D., Dingwall, A., Alderson, R., Campbell, P., Bickerdike, R. (2006) Muscle and flesh quality traits in wild and farmed Atlantic salmon. Aquaculture 256, 323-336.

Kolkovski, S. (2001) Digestive enzymes in fish larvae and juveniles - implications and applications to formulated diets. Aquaculture 200, 181-201.

Kotzamanis, Y.P., Gisbert, E., Gatesoupe, F.J., Zambonino Infante, J., Cahu, C. (2007) Effects of different dietary levels of fish protein hydrolysates on growth, digestive enzymes, gut microbiota, and resistance to Vibrio anguillarum in European sea bass (Dicentrarchus labrax) larvae. Comparative Biochemistry and Physiology, Part A 147, 205-214.

Koumoundouros, G., Ashton C., Xenikoudakis, G., Giopanou, I., Georgakopoulou, E., Stickland, N. (2009) Ontogenetic differentiation of swimming performance in Gilthead seabream (Sparus aurata, Linnaeus 1758) during metamorphosis. Journal of Experimental Marine Biology and Ecology 370, 75-81.

Koumoundouros, G., Divanach, P., Kentouri, M. (1999) Osteological development of the vertebral column and the caudal complex in Dentex dentex. Journal of fish Biology 54, 424-436.

Koumoundouros, G., Divanach, P., Kentouri, M. (2001) The effect of rearing conditions on development of saddleback syndrome and caudal fin deformities in Dentex dentex (L.). Aquaculture 200, 285-304. 
Koumoundouros, G., Maingot, E., Divanach, P., Kentouri, M. (2002) Kyphosis in reared sea bass (Dicentrarchus labrax L.): ontogeny and effects on mortality. Aquaculture 209, 4958.

Kjørsvik, E., Olsen, C., Wold, P.A., Hoehne-Reitan, K., Cahu C.L., Rainuzzo, J., Olsen, A.I., Øie, G., Olsen, Y. (2009) Comparison of dietary phospholipids and neutral lipids on skeletal development and fatty acid composition in Atlantic cod (Gadus morhua). Aquaculture 294, 246-255.

Kvåle, A., Mangor-Jensen, A., Moren, M., Espe, M., Hamre, K. (2007) Development and characterisation of some intestinal enzymes in Atlantic cod (Gadus morhua L.) and Atlantic halibut (Hippoglossus hippoglossus L.) larvae. Aquaculture 264, 457-468.

Lall, S.P., Lewis-McCrea, L.M. (2007) Role of nutrients in skeletal metabolism and pathology in fish - An overview. Aquaculture 267, 3-19.

Le Vay, L., Carvalho, G.R., Quinitio, E.T., Lebata, J.H., Ut, V.N., Fushimi, H. (2007) Quality of hatchery-reared juveniles for marine fisheries stock enhancement. Aquaculture 268, 169-180.

Lewis, L.M., Lall, S.P., Witten, P.E. (2004) Morphological descriptions of the early stages of spine and vertebral development in hatchery-reared larval and juvenile Atlantic halibut. Aquaculture 241, 47-59.

Loy, A., Boglione, C., Gagliardi, F., Ferrucci, L., Cataudella, S. (2000) Geometric morphometrics and internal anatomy in sea bass shape analysis (Dicentrarchus labrax L., Moronidae). Aquaculture 186, 33-44.

Ma, H., Cahu, C., Zambonino, J., Yu, H., Duan, Q., Le Gall, M.M., Mai, K. (2005) Activities of selected digestive enzymes during larval development of large yellow croaker (Pseudosciaena crocea). Aquaculture 245, 239 - 248.

Mairesse, G., Thomas, M., Gardeur, J.-N., Brun-Bellut, J. (2005) Appearance and technological characteristics in wild and reared Eurasian perch, Perca fluviatilis (L.). Aquaculture 246, 295-311.

Maroux, S., Louvard, D., Baratti, J. (1973) The aminopeptidase from hog-intestinal brush border. Biochimica et Biophysica Acta 321, 282- 295.

Masson, P.J. (1929) Some histolological methods: trichrome staining and their preliminary technique. Journal of Technical Methods 12, 75-29.

Mcdonald, D.G., Milligan, C.L., Mcfarlane, W.J., Croke, S., Currie, S., Hooke, B., Angus, R.B., Tufts, B.L., Davidson, K. (1998) Condition and performance of juvenile Atlantic salmon (Salmo salar): Effects of rearing practices on hatchery fish and comparison with wild fish. Canadian Journal of Fisheries and Aquatic Sciences 55, 1208-1219.

McCormick, S.D., Björnsson, B.T. (1994) Physiological and hormonal differences among Atlantic salmon parr and smolts reared in the wild, and hatchery smolts. Aquaculture 121, 235-244.

Métais, P., Bieth, J. (1968). Determination de l'a-amylase par une microtechnique. Annales de biologie clinique 26, 133-142.

Nasopoulou, C., Nomikos, T., Demopoulos, C.A., Zabetakis, I. (2007) Comparison of antiatherogenic properties of lipids obtained from wild and cultured sea bass (Dicentrarchus labrax) and gilthead sea bream (Sparus aurata). Food Chemistry 100, 560-567

Nicholson, J.A., Kim, Y.S. (1975) A one-step I-amino acid oxidase assay for intestinal peptide hydrolase activity. Analytical biochemistry 63, 110-117.

Ogata, H.Y., Oku, H., Murai, T. (2002) Growth performance and macronutrient retention of offspring from wild and selected red sea bream (Pagrus major). Aquaculture (206) 279287.

Ortiz-Delgado, J.B., Darias, M.J., Cañavate, J.P. ,Yúfera, M., Sarasquete, C. (2003) Organogenesis of the digestive tract in the white seabream, Diplodus sargus. Histological and histochemical approaches. Histology and Histopathology 18, 1141-1154.

Osse, J.W.M., Van den Boogaart, J.G.M., Van Snick, G.M.J., Van der Sluys, L. (1997) Priorities during early growth of fish larvae. Aquaculture, 155, 249-258. 
Papadakis, I.E., Zaiss, M.M., Kyriakou, Y., Georgiou, G., Divanach, P. Mylonas, C.C., (2009) Histological evaluation of the elimination of Artemia nauplii from larval rearing protocols on the digestive system ontogeny of shi drum (Umbrina cirrosa L.). Aquaculture 286, 4552.

Pavlidis, M., Papandroulakis, N., Divanach, P. (2006) A method for the comparison of chromaticity parameters in fish skin: Preliminary results for coloration pattern of red skin Sparidae. Aquaculture 258, 211-219.

Pedersen, B.H., Ueberschär, B., Kurokawa, T. (2003). Digestive response and rates of growth in pre-leptocephalus larvae of the Japanese eel Anguilla japonica reared on artificial diets. Aquaculture 215, 321-338.

Péres, A., Zambonino Infante, J.L., Cahu, C.L. (1998). Dietary regulation of activities and mRNA levels of trypsin and amylase in sea bass (Dicentrarchus labrax) larvae. Fish Physiology and Biochemistry 19, 145-152.

Periago, M.J., Ayala, M.D., Lopez-Albors, O., Abdel, I., Martinez, C., Garcia-Alcazar, A., Rosa, G., Gil, F. (2005). Muscle cellularity and flesh quality of wild and farmed sea bass, Dicentrarchus labrax L. Aquaculture 249, 175-188.

Przybyl, A., Ostaszewska, T., Mazurkiewicz, J., Wegner, A. (2006) The effect of experimental starters on morphological changes in the intestine and liver of common carp (Cyprinus carpio L.) larvae reared under controlled conditions. Archives of Polish Fisheries 14(1), 67-83.

Roncarati, A., Meluzzi, A., Melotti, P., Mordenti, O. (2001) Influence of the larval rearing technique on morphological and productive traits of European sea bass (Dicentrarchus labrax L.). Journal of applied Ichthyology 17, 244-246.

Roo, J., Socorro, J., Izquierdo, M. S. (2010) Effect of rearing techniques on skeletal deformities and osteological development in red porgy Pagrus pagrus (Linnaeus, 1758) larvae. Journal of Applied Ichthyology 26, 372-376

Ruiz, O., Amat, F., Navarro, J.C. (2008) A comparative study of the fatty acid profile of Artemia franciscana and $A$. persimilis cultured at mesocosm scale. Journal of Experimental Marine Biology and Ecology 354, 9-16.

Saglik, S., Alpaslan, M., Gezgin, T., Cetintürk, K., Tekinay, A., Güven, K.C. (2003) Fatty acid composition of wild and cultivated gilthead seabream (Sparus aurata) and sea bass (Dicentrarchus labrax). European Journal of Lipid Science and Technology 105, 104-107.

Sfakianakis, D.G., Georgakopoulou, E., Papadakis, I.E., Divanach, P., Kentouri, M., Koumoundouros, G. (2006) Environmental determinants of haemal lordosis in European sea bass, Dicentrarchus labrax (Linnaeus, 1758). Aquaculture 254, 54-64.

Shields, R. J. (2001) Larviculture of marine finfish in Europe. Aquaculture 200, 55-88.

Smith, M.E., Fuiman, L.A. (2004) Behavioral performance of wild-caught and laboratoryreared red drum Sciaenops ocellatus (Linnaeus) larvae. Journal of Experimental Marine Biology and Ecology 302, 17-33.

Stunz, G.W. Minello T.J. (2001) Habitat-related predation on juvenile wild-caught and hatchery-reared red drum Sciaenops ocellatus (Linnaeus). Journal of Experimental Marine Biology and Ecology 260, 13-25.

Sundell, K., Dellefors, C., Björnsson, B. (1998) Wild and hatchery-reared brown trout, Salmo trutta, differ in smolt related characteristics during parr-smolt transformation. Aquaculture 167, 53-65.

Taylor, W. R., Van Dyke G. C. (1985) Revised procedures for staining and clearing small fishes and other vertebrates for bone and cartilage study. Cybium II 9, 107-119.

Utne-Palm, A.C. (2004) Effects of larvae ontogeny, turbidity, and turbulence on prey attack rate and swimming activity of Atlantic herring larvae. Journal of Experimental Marine Biology and Ecology 310, 147-161.

Vagner, M., Robin, J.H., Zambonino Infante, J.L., Person-Le Ruyet, J. (2007) Combined effects of dietary HUFA level and temperature on sea bass (Dicentrarchus labrax) larvae development. Aquaculture 266, 179-190. 
van der Meeren, T., Naas, K.E. (1997) Development of rearing techniques using large enclosed ecosystems in the mass production of marine fish fry. Reviews in Fisheries Science 5, 367-390.

van der Meeren, T., Olsen, R.E., Hamre, K., Fyhn, H.J. (2008) Biochemical composition of copepods for evaluation of feed quality in production of juvenile marine fish. Aquaculture 274, 375-397.

van Snik, G.M.J., van den Boogaart, J.G.M., Osse J.W.M. (1997) Larval growth patterns in Cyprinus carpio and Clarias gariepinus with attention to finfold. Journal of Fish Biology $50,1339-1352$.

Villeneuve, L.A.N., Gisbert, E., Moriceau, J., Cahu, C., Zambonino Infante, J.L. (2006) Intake of high levels of vitamin A and polyunsaturated fatty acids during different developmental periods modifies the expression of morphogenesis genes in European sea bass (Dicentrarchus labrax). British Journal of Nutrition 95(4), 677-687.

von Cramon, N, Ling, E.N, Cotter, D, Wilkins, N.P. (2005). Determination of body shape variation in Irish hatchery-reared and wild Atlantic salmon. Journal of Fish Biology 66(5), 1471-1482.

Zambonino Infante, J.L., Cahu, C. (1994) Development and response to a diet change of some digestive enzymes in sea bass (Dicentrarchus labrax) larvae. Fish Physiology and Biochemistry 12 (5), 399-408.

Zambonino Infante, J.L., Cahu, C. (2001) Ontogeny of gastrointestinal tract of marine fish larvae. Comparative Biochemistry and Physiology C, 130, 477-487.

Zambonino Infante, J.L., Cahu, C.L., Péres, A., Quazuguel, P., Le Gall, M.M. (1996) Sea bass (Dicentrarchus labrax) larvae fed different Artemia rations: growth, pancreas enzymatic response and development of digestive functions. Aquaculture 139, 129-138.

Zar, J. H. (1999) Biostatistical Analysis (4th Edition). Prentice Hall, Englewood Cliffs, 663 pp.

Zhou, X.Q., Zhao, C.R., Lin, Y. (2007) Compare the effect of diet supplementation with uncoated or coated lysine on juvenile Jian Carp (Cyprinus carpio Var. Jian). Aquaculture Nutrition, 13, 457-461.

Zouiten, D., Ben Khemis, I., Besbes, R., Cahu, C. (2008) Ontogeny of the digestive tract of thick lipped grey mullet (Chelon labrosus) larvae reared in "mesocosms". Aquaculture 279, 166-172. 
Table 1. Morphological criterions used to determine developmental stages of 37 days old sea bass Dicentrarchus labrax after double coloration (alcian blue/alizarin red) of skeletal structures.

\begin{tabular}{|c|l|}
\hline Developmental stages & \multicolumn{1}{c|}{ Morphological criterions } \\
\hline A & - Absence of ossification \\
\hline B & - Ossification limited to the first three vertebrae \\
\hline C & - Ossification of head, caudal fine and back bones \\
\hline D & $-\begin{array}{l}\text { Ossification of secondary dorsal fine and appearance of } \\
\text { "bud of primer dorsal fine" }\end{array}$ \\
\hline E & - Presence of a developed primary dorsal fine \\
\hline
\end{tabular}

Table 2. Maturation index of sea bass Dicentrarchus labrax larvae reared either with the intensive (Int.) or the mesocosm (Mes.) technology.

Maturation index are expressed as alkaline phosphatase (AP) and aminopeptidase $N$ (AN) segmental activity in brush border membrane related to segmental leucine-alanine peptidase (leu-ala) activity in intestinal segment of larvae. Data are given as mean (x103) \pm SD $(n=3)$ and are expressed in \%. (x103). Values with different (a-b) superscript letters indicate difference related to rearing technique (int or mes), values with different $(x-y)$ superscript letters indicate difference related to development day $(P<0.05$; ANOVA followed by NewmanKeuls test). Interaction of age $X$ treatment was not significant.

\begin{tabular}{llccc}
\hline & & day 23 & day 30 & day 37 \\
\hline \multirow{2}{*}{ AP/Leu-ala } & Int. & $24.8 \pm 2.7^{\text {by }}$ & $92.2 \pm 29.5^{\text {ax }}$ & $85.7 \pm 6.9^{\text {ax }}$ \\
& Mes. & $78.8 \pm 10.8^{\text {ax }}$ & $107.2 \pm 10.0^{\text {ax }}$ & $120.6 \pm 32.3^{\text {ax }}$ \\
& & & & \\
AN/Leu-ala & Int. & $8.1 \pm 2.8^{\text {by }}$ & $27.9 \pm 8.1^{\text {ax }}$ & $27.1 \pm 1.7^{\text {ax }}$ \\
& Mes. & $30.4 \pm 3.1^{\text {ax }}$ & $31.9 \pm 5.5^{\text {ax }}$ & $52.6 \pm 8.3^{\text {ax }}$ \\
\hline
\end{tabular}




\section{Figures}

Figure 1. Wet weight growth of sea bass Dicentrarchus labrax larvae reared either with the intensive or the mesocosm technology. Data are given as mean \pm SD and are expressed in $\mathrm{mg}$ on a logarithmic scale. Values with different $(a-b)$ superscript letters indicate difference related to rearing technique (int or mes); values with different ( $\mathrm{v}-\mathrm{z})$ superscript letters indicate difference related to development day $(P<0.05)$. Interaction of age $X$ treatment was not significant $(\mathrm{P}=0.399)$.

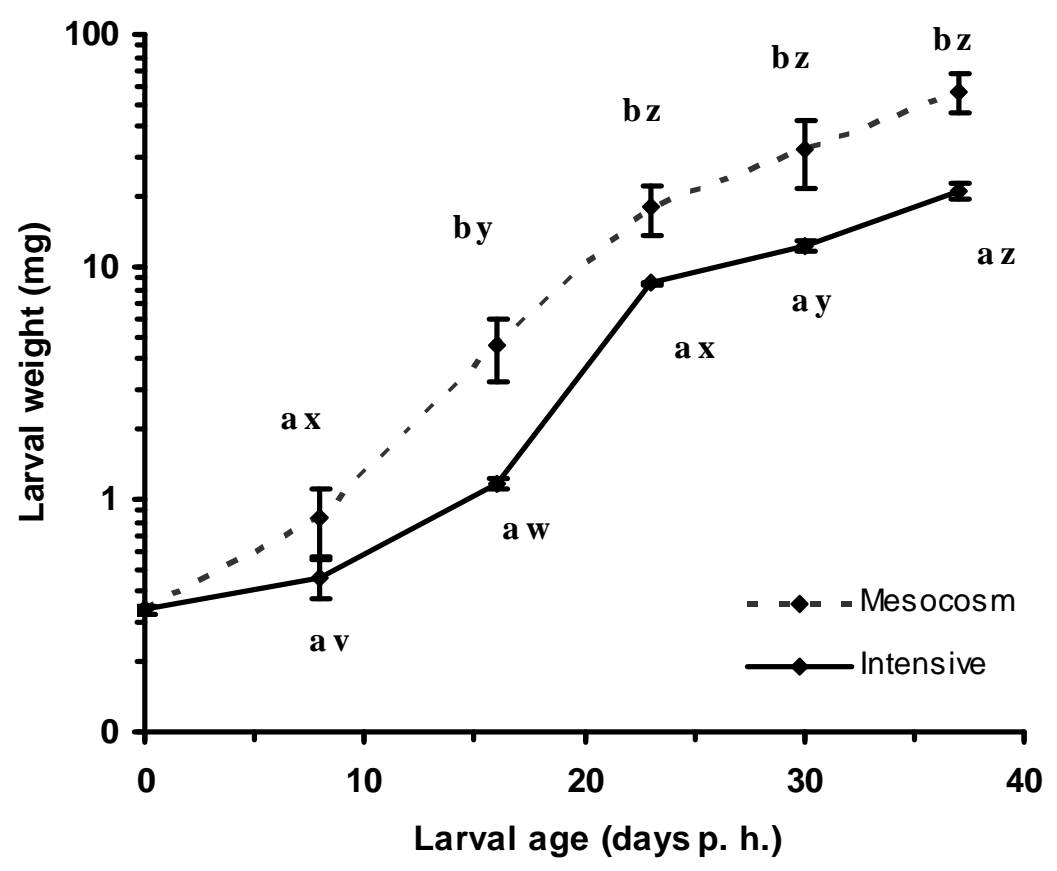


Figure 2. Secretion rates of trypsin (a) and amylase (b) during development of sea bass Dicentrarchus labrax larvae reared either with the intensive or the mesocosm technology. Data are given as mean \pm SD and are expressed in (\%). Values with no common ( $\alpha-\delta)$ superscript letters are significantly different $(P<0.05$; two-way ANOVA followed by NewmanKeuls test for interaction factor). Interaction of age $x$ treatment was significant $(P=0.034)$ for trypsin and highly significant $(P=0.009)$ for amylase.
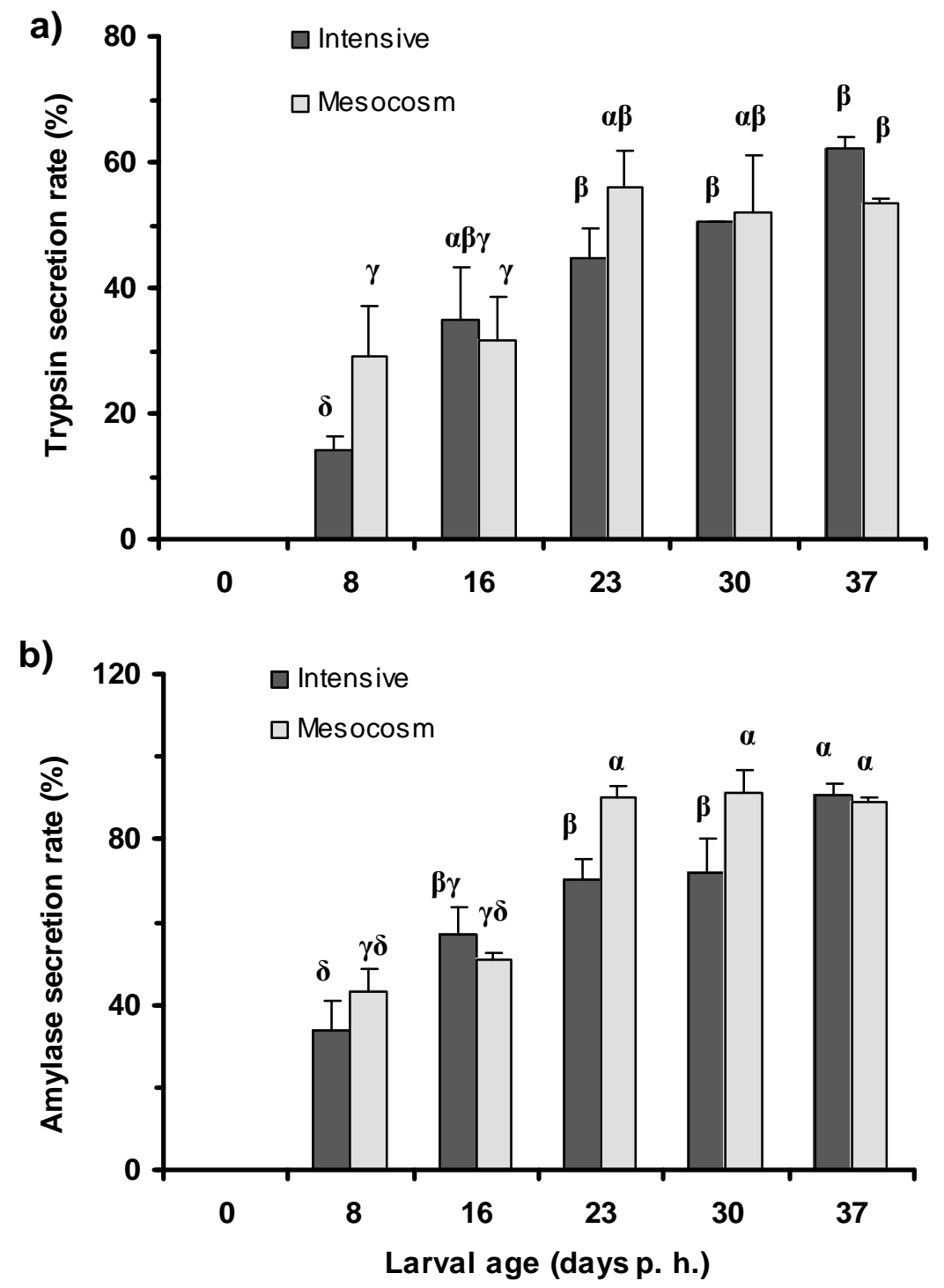
Figure 3. Sagittal sections showing epithelium of middle intestine in 23 days old sea bass (Dicentrarchus labrax) larvae reared either with the mesocosm (a: GX10 and b: GX40) or the intensive (c: GX10 and d: GX40) technology. Staining with Masson Goldner trichromic. Abbreviations: $\mathrm{BB}=$ brush border; $\mathrm{E}=$ entenrocystes; $\mathrm{IL}=$ intestinal lumen; $\mathrm{M}=$ muscles ; $\mathrm{V}=$ Intestinal villosity;.
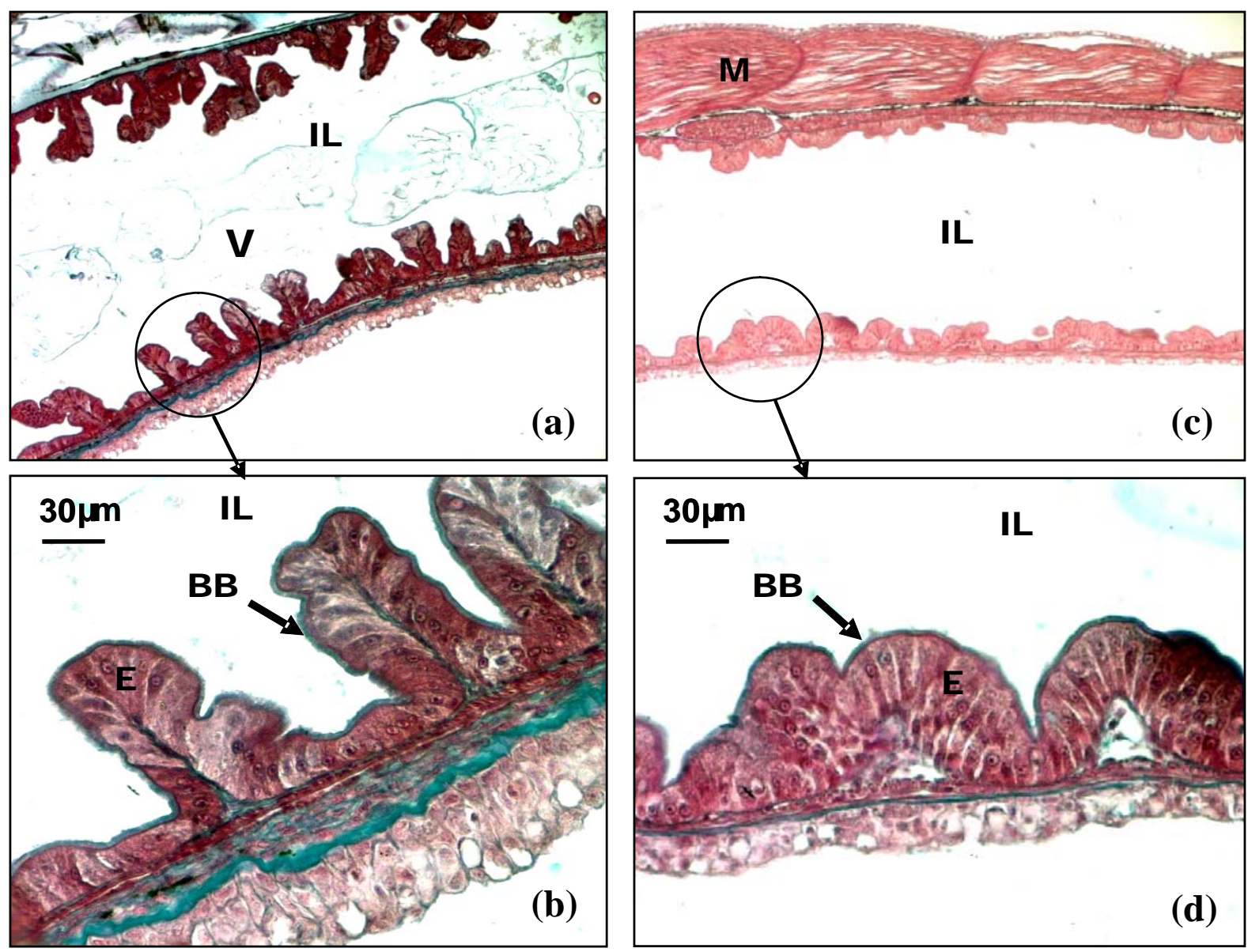
Figure 4. Relative frequencies distributions of vertebrae count (a) and skeletal development stages (b) determined after double coloration (alcian blue/alizarin red) of skeletal structures, 37 days old sea bass Dicentrarchus labrax, reared either with the intensive or the mesocosm technology.

a)

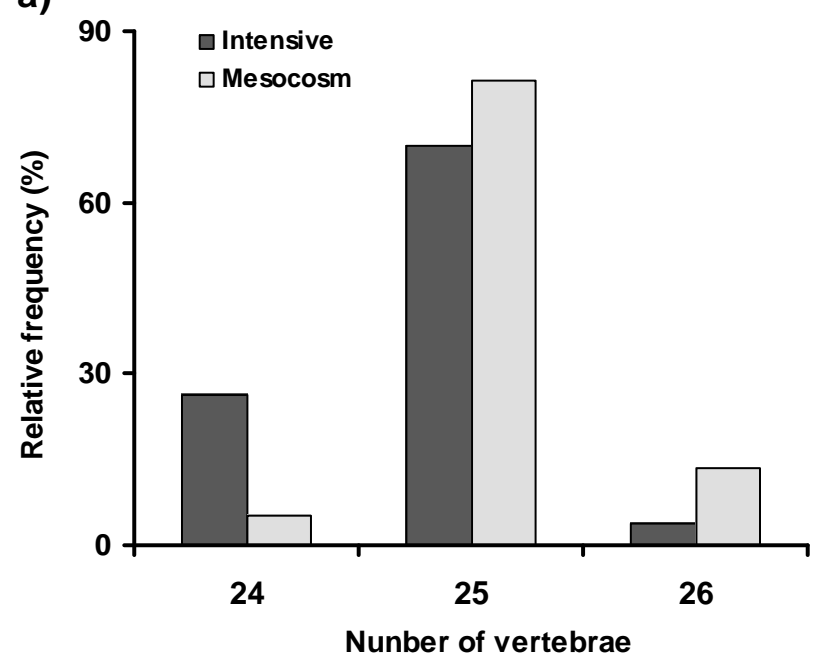

b)

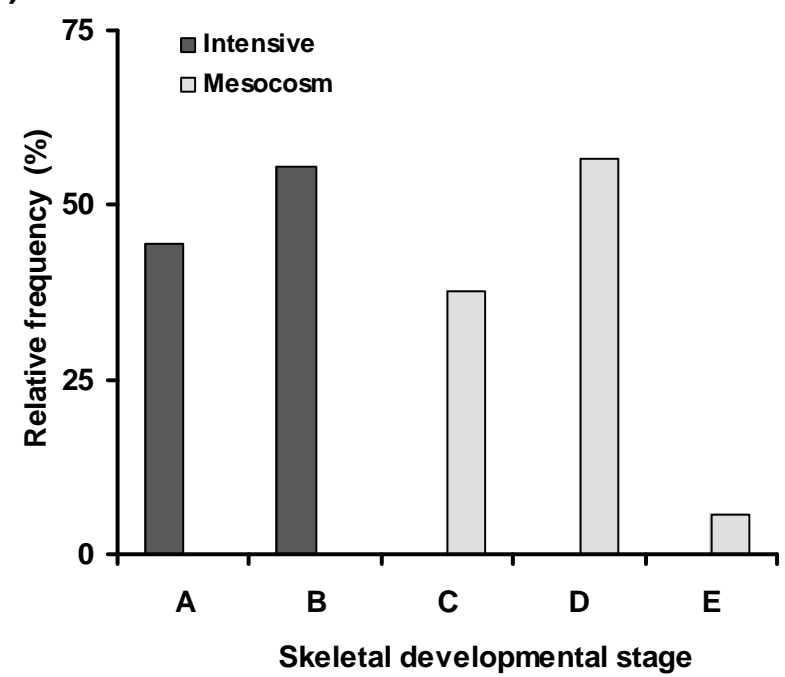

Figure 5. Mesocosm (a) and intensive (b) reared 37 days old sea bass Dicentrarchus labrax, after double coloration (alcian blue/alizarin red) of skeletal structures distinguishing between ossified bones (in red) and cartilage (in bleu). According to morphological criterion described in table 1, the Fig. 5(a) represents a larva at ossification stage $E$ and the Fig. 5(b) represents a larva at ossification stage B.
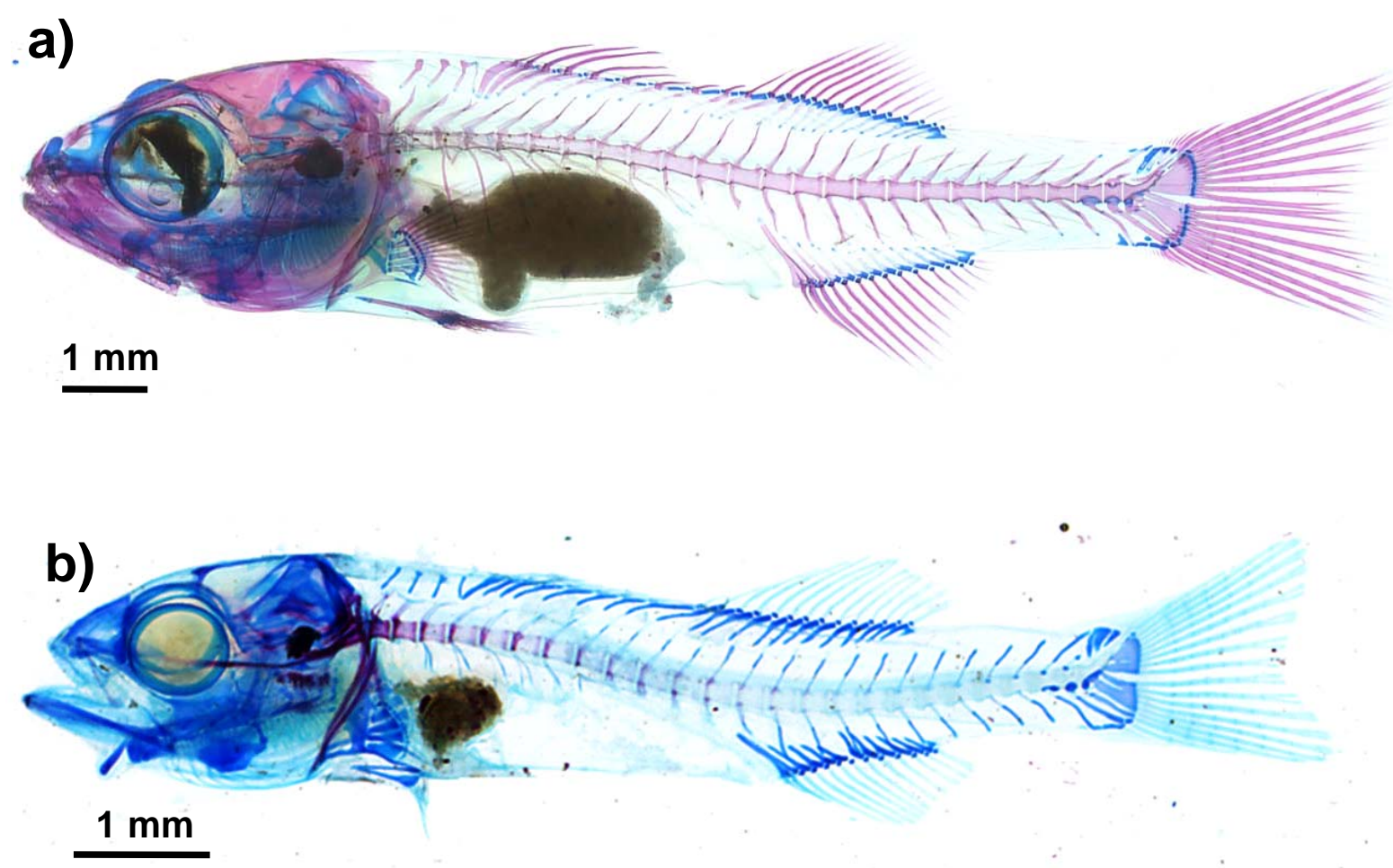
Figure 6. Incidence of the types of deformities in 37 days old sea bass Dicentrarchus labrax larvae reared either with the intensive or the mesocosm technology. Operculum deformities were not counted, $\left(^{*}\right)$ indicate vertebral compression or fusion with no apparent body distortion, and $2+$ is the incidence of fish showing two or more deformities.

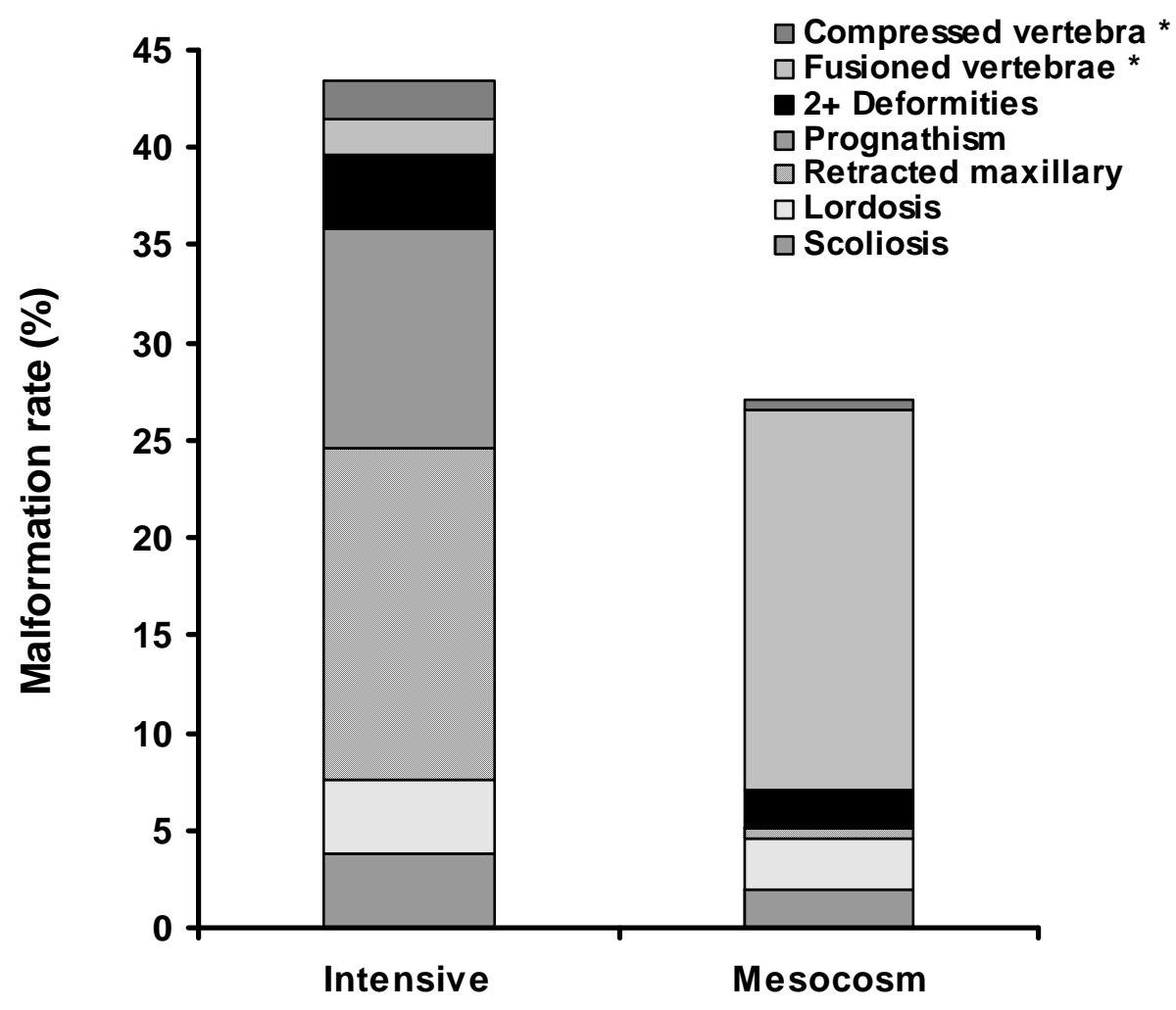

